\title{
Social Capital as the Missing Link in Community Development Planning Process in Africa: Lessons from Ghana
}

\author{
Ronald Adamtey \\ Department of Planning \\ Kwame Nkrumah University of Science and Technology, Kumasi-Ghana \\ radamteysekade@gmail.com \\ or radamtey.cap@knust.edu.gh \\ and \\ Josephine Frimpong \\ Department of Planning \\ Kwame Nkrumah University of Science and Technology, Kumasi-Ghana \\ DOI//http://dx.doi.org/10.4314/gjds.v15i1.5
}

\begin{abstract}
Abstracct
Conventional community development strategies have focused on the importance of physical, natural, financial, and human capitals. In spite of the emphasis on these in the pursuit of development, a number of community development problems persist. Given the huge evidence that social capital matters in community development efforts, it appears that the missing link in community development is social capital. Yet this has not been adequately explored. This paper explores the role of social capital in the community development planning process. Comparative case study design was used. Two rural communities were selected from the Ejisu-Juaben Municipal Area for indepth study. Interviews were conducted with the principal and assistant Municipal Planning officers and two Principal Community Development Officers from the Municipal Assemblies and the traditional leaders of both communities. Assembly members were used as key informants. Focus group discussions were held with community groups. Forty respondents were randomly selected at the household level and interviewed. The analysis focused on social networks, trust, civic engagement and social norms. It was found that social capital could facilitate the community development planning process by promoting the participation of community members in community activities, increase their ability to work together and engender overall development. There is a correlation between community development and the level of social capital. The paper recommends
\end{abstract}


that development planning at the sub-national levels can be more responsive if it utilizes networks and social ties in the preparation and implementation of plans.

Keywords: Social Capital, Development, Planning, Ghana, Participation

\section{Introduction}

Planning is a process of reflection that guides actions. As noted by Kent (1981: 1), 'planning means deliberate systematic efforts designed to guide future decisions and action.' Planning helps communities create their preferred future (Litman, 2013). A definition which serves best for this paper sees planning as 'a continuous process which involves making decisions about alternative ways of using available resources with the aim of achieving particular goals at some time in the future' (Conyers \& Hills, 1984:62). This definition views planning as a process of change consisting of consciously preconceived consistent sequence of actions aiming to achieve particular goals. Planning local community development is a progressive way to achieving development in the entire nation as the development of local communities culminates into the ultimate development of the nation.

Community development planning as used in this paper refers to the decision making process through which the needs of people in a defined geographic area are addressed to ensure an improvement in their living conditions. In planning community development, the planning process helps to create the positive change expected by community members as well as Planners. Planning as a social activity involves people and as Friedman and Fraser (2015) argued getting community members involved is a primary goal linked to successful outcomes in community development planning.

The common problem that Development Planners face is the scarcity of resources (Conyers \& Hills, 1984) and planning helps to effectively focus limited resources on activities that are most likely to bring about the desired change (Todaro \& Smith, 2011). Many community development strategies and conventional planning approaches have focused on the development of physical, natural, financial, and human capitals (Tirmizi, 2005). In spite of the emphasis on these approaches in the pursuit of development, a number of community development issues such as apathy and weak commitment to community development issues by citizens persist.

One explanation to the many community development problems is apathy among community members (Innes \& Booher, 2010). Apathy has contributed to low participation in the development planning process. This view also supported by 
Cavaye (2001) suggests that community leaders and volunteers are struggling to foster broader participation for community development. The low level of interest and commitment among community members have contributed to a breakdown of community initiatives as well as weak support for externally driven development initiatives. To this end MacLaran et al. (2007) assert that everything necessary is done to promote the participation of communities in the process of community development planning.

In addressing the issue of apathy and low participation in the community development planning process, one area that appears to have received inadequate scholarly attention is the concept of social capital. This paper argues that social capital has a huge promise in facilitating community development planning in Africa. Many African societies have huge stock of social capital which manifest in extended family systems, networks and ties built around religion, ethnicity and kingship (Miruka \& Omenya, 2009).

Social capital has been used here to mean a social resource developed through networks of people, relationships of trust and reciprocity together with social norms that enable social organisations to act together to pursue common objectives. This definition is informed by many community development scholars who claim that communities with a good stock of social capital are more likely to develop; and this will manifest in lower crime figures, better health, higher educational achievement, and better economic growth (Coleman 1988; Putnam et al., 1993). For the purposes of this paper, social capital has been operationalised using four components which are social networks, trust, civic engagement and social norms.

The word 'social capital' was first used by Lyda Judson Hanifan about a century ago (see Putnam and Goss, 2002; Woolcock and Narayan, 2000). However the works of Pierre Bourdieu, James Coleman and Robert Putnam have been credited for the contemporary re-emergence of the concept of social capital (Portes, 1998; Tzanakis, 2013). Social capital has been credited with a range of potential beneficial effects including effectiveness of formal institutions (Dhesi, 2000), economic development (Putnam et al., 1993), public health (Erikkson, 2010; Hawe \& Shiell, 2000), education (Coleman, 1988) and rural development (Wiesinger, 2007).

\section{Social Capital and Community Development}

Many scholars have described social capital as the missing link in development (Butler et al., 2009; Dhesi, 2000; Grootaert, 1998). This claim is based on the view of social capital as networks, relationships and norms that help citizens to 
solve collective problems more easily through coordination and communication (Putnam, 1995). Indeed, there is a growing consensus showing a positive correlation between social capital and community development. Cavaye (2004) draws attention to the benefits of social capital to the community and asserts that social capital is both a means and an end. As a means, it mediates relationships and participation that lead to concrete outcomes such as community owned assets. As an end, the relationships and networks that mediate action are strengthened in themselves, increasing cooperation between individuals and the function of organisations. Consequently, scholars like Bullen (2007) and Debertin and Goetz (2013) are of the view that social capital is a prerequisite for community development processes.

Community development here refers to the process of identifying community priorities and addressing local problems by communities working in partnership with local governments and other supportive institutions (Tirmizi, 2005; World Bank, 2014). It involves community members mobilizing themselves using community structures to initiate actions to address their needs and empower groups of people (Mendes, 2009). The main objective of community development is to integrate community members and groups into the process of organizing and mobilizing resources for community improvement, which in turn improves their lives. It is therefore an inclusive approach to working with people who participate in the process. To this end, indicators to assess community development should reflect the characteristics of communities that influence their ability to address social needs and empower people. Participation in community activities; ability to work together and avoid factionalisms; and how well community members are informed on local issues were identified as key features of communities which reflect both community development and the community's social capital situation (Phillips \& Pittman, 2008). Subsequently these indicators have been used in determining the state of community development in the study communities.

\section{Social capital and community development planning}

Kennedy (1996) has supported the role of planning in community development by noting that community development is not ultimately the existence of financial or physical capital, or human capital, but it is the capacity of a society to tap into these resources to address its needs. Planning ensures that community resources are applied to steer social, political, economic or physical processes to change situations to a desired future situation (Van Dusseldorp, 1991).

Although community development planning utilizes physical, human, financial and environmental capital, there is the argument that for community development to be successful, social capital needs to be considered as a catalyst to facilitate the 
process (Tirmizi, 2005). To support this position, Cavaye (2004) and Bullen (2007) argue that social capital plays a crucial role in community development, making it a prerequisite for community development processes.

Holman and Rydin (2012) acknowledge the problem of engaging and sustaining the interest of community members in the planning process as a major setback to community development. Although some approaches have been adopted in the past, these approaches have failed to attract a wider section of the community. Some of these approaches are the use of public campaigns and consultation exercises, and innovative deliberative measures such as citizens' juries and deliberative panels (Holman \& Rydin, 2012). In view of this, Rydin and Pennington (2000) propose that a new approach is developed which breaks what they term the collective action problem that constrains participation. The collective action problem is described by Holman and Rydin (2012) as the perception that costs of participating in planning is high and the possible future benefits cannot offset this loss. To overcome this problem, Holman and Rydin (2012) suggest the building of social capital within the local community as social capital has the potential of creating networks between people that are governed by some basic norms such as trust. Such basic norms induce the commitment of community members and motivate them to participate.

In describing how social capital can be beneficial to community development planning, Friedman and Fraser (2015) note that communities with high social capital have individuals that are socially active and trusting. In such communities, there is a greater chance that community members would support community level efforts to achieve community level goals. van Kinderen (2006) also notes that social capital can help in improving planning outcomes as it helps to incorporate indigenous knowledge, generate creative alternatives, and enrich the overall policy discussion. In Ghana, Adjargo (2012); and van Kinderen (2006) have acknowledged the importance of social capital in community development asserting that Ghanaians achieved impressive feat in the past by using social capital. The importance of social capital is apparent.

In spite of all the claims about the usefulness of social capital and the evidence of this in community development, there remains the question of how community development planning process can incorporate social capital. This paper therefore contributes to the debate by showing how community development planning process can incorporate the ideals of social capital. 


\section{Study Context and Methodology}

The Ejisu-Juaben Municipality was selected because it was judged the best performing Municipality in terms of governance, initiation and implementation of development projects and the promotion of community development among all 216 Metropolitan, Municipal and District Assemblies in Ghana in 2014 (see Myjoyonline, 2015). In addition, Ejisu-Juaben Municipality has vibrant community development activities aimed at ensuring a wider participation of citizens in governance (Ejisu-Juaben Municipal Assembly, 2010). Meetings were held with the Development Planning officers and the Community Development officers at the Ejisu-Juaben Municipal Assembly which led to the initial selection of four communities in the municipality. A reconnaissance survey was conducted in these communities using a set of survey questions. Onwe and Kwaso communities were selected in the Municipality because they have similar social contexts, similar community resources but varying levels of community development (Ejisu-Juaben Municipal Assembly, 2010).

Onwe is one of the communities located at the Western part of the Ejisu-Juaben Municipal area (see Figure 1). It is approximately seventeen kilometres away from Ejisu the capital of the Municipality. With a population of 4,343 inhabitants Onwe ranks $8^{\text {th }}$ on the list of the top twenty populated settlements of the Ejisu-Juaben Municipal area (Ghana Statistical Service, 2014). The community hosts the Onwe Zonal Council, one of the nine Zonal Councils of the Ejisu-Juaben Municipal Assembly (Ejisu-Juaben Municipal Assembly, 2010).

Kwaso is also located at the Western part of the Ejisu-Juaben Municipal area approximately twenty-three kilometres away from Ejisu (see Figure 1). Kwaso and Onwe are both along the same transport corridor connected by a second-class road. Kwaso is approximately six kilometres from Onwe. The community ranks $7^{\text {th }}$ (in terms of population) on the list of top 20 settlements in the Ejisu-Juaben Municipal area. Kwaso has a population of 4,427 inhabitants (Ghana Statistical Service, 2014). It is the capital of the Mponua Zonal Council of the Ejisu-Juaben Municipal Assembly (Ejisu-Juaben Municipal Assembly, 2010). Comparable to other communities in the Municipality, both Kwaso and Onwe are governed by a traditional authority. 


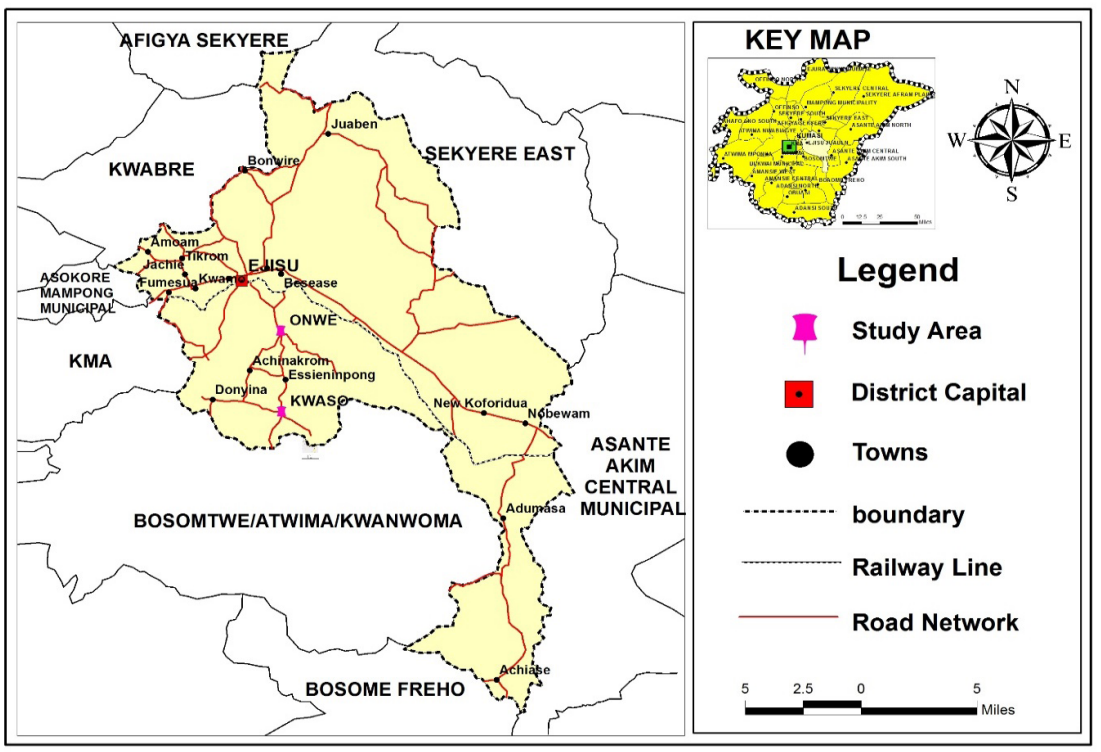

Figure 1: Study communities in Municipal context

Source: Adapted from maps.google.com.gh, 2016

This paper is a comparative case study relying on qualitative data (Thomas, 2014). Four indicators of community development have been employed in the analysis of how social capital matters. These are participation in community activities; the ability to work together and avoid factionalisms; how well-informed community members are on local issues; and initiation of community projects. The forms of social capital used in this paper are social networks, trust, civic engagement and social norms. Social networks were measured by the membership of community members in groups and associations. Trust was measured by the extent to which people believe that their neighbours would treat them the way they expected. This was measured as either always, mostly, sometimes, rarely and never. Civic engagement refers to the intentional sense of responsibility towards community which is reflected in actions such as joining political parties or working on public problems (Hua \& Wan, 2011). Civic engagement was operationalised in terms of citizens' involvement in actions to help address local problems. Regarding social norms, the study considered norms of fairness.

Data for the study were collected between October 2016 and January 2017 from five sources: key informants, high profile officers of the District Assembly, local councilors, households and focus groups. In depth interviews were held with key informants, high profile officers and councilors on the existence of social capital and the extent to which this explains the development of their communities. 
This was followed by semi-structured interviews with 40 households who were randomly selected from each community. The household interviews were used to validate the data obtained from the key informants and the officials and also to pick further data on social capital. In addition, focus group discussions were held with two community-based groups in each study community. All the interviews were recorded, transcribed and analysed using Nvivo.

\section{Findings and Discussions}

\section{Formation of Groups and Social Networks}

The study found that community members in both cases cherished social networks. These networks include religious groups, political party groups, personal development groups, professional groups, school associations and trade associations. The household interviews showed that the most prominent were religious groups (see Table 1). In Onwe, at least one member of each household interviewed belong to a religious group while in Kwaso 95 percent of households belong to religious groups. The second most prominent category of groups was the political party groups followed by the Personal Development groups where 15 percent of respondents in Onwe and about 8 percent of respondents in Kwaso belong to. Personal Development groups (PDs) are associations such as fun clubs and local groups whose only identity is that they are made up of members with the same interest in the pursuit of personal growth. One of such PDs is the 'mmerewa ne nkokraku' (Club of the Elderly) whose motto is 'mmasriwa, yedi yen ho ni' meaning 'as elders we cherish discipline and uphold high moral standards.' These groups and associations offered a platform where local residents could meet other local people to share experiences, inspire, encourage and help each other. These groups cut across both horizontal and vertical links among community members and between community members and leaders. 
Table 1: The different associations in study communities

\begin{tabular}{|c|c|c|c|c|}
\hline \multirow[t]{2}{*}{ Group } & \multicolumn{2}{|l|}{ Onwe } & \multicolumn{2}{|l|}{ Kwaso } \\
\hline & Frequency & Percentage & Frequency & Percentage \\
\hline Religious Groups & 40 & 100 & 38 & 95 \\
\hline Political Groups & 7 & $17 \cdot 5$ & 8 & 20 \\
\hline $\begin{array}{l}\text { Personal } \\
\text { Development(PD) Groups }\end{array}$ & 6 & 15 & 3 & $7 \cdot 5$ \\
\hline Professional associations & 6 & 15 & 4 & 10 \\
\hline School association(PTA) & 6 & 15 & 7 & $17 \cdot 5$ \\
\hline $\begin{array}{l}\text { Trade Organisation/ } \\
\text { Farmers Groups }\end{array}$ & 1 & 2.5 & 5 & 12.5 \\
\hline \multirow[t]{2}{*}{ Number of Groups } & \multicolumn{2}{|l|}{ Onwe } & \multicolumn{2}{|l|}{ Kwaso } \\
\hline & Frequency & Percentage & Frequency & Percentage \\
\hline None & - & & 2 & 5 \\
\hline 1 & 13 & 32.5 & 11 & $27 \cdot 5$ \\
\hline 2 & 20 & 50 & 19 & 47.5 \\
\hline 3 & 6 & 15 & 8 & 20 \\
\hline 4 & 1 & 2.5 & - & - \\
\hline Total & 40 & 100 & 40 & 100 \\
\hline
\end{tabular}

Source: Field survey, January, 2017

All the respondents in Onwe were members of at least one group or association. While about 33 percent of respondents in Onwe belonged to one group, half of the respondents belonged to two groups. Also 15 percent of respondents belonged to three groups. The highest number of groups that respondents could belong to was four and Onwe recorded the highest with one respondent belonging to four associations. It is important to note that all the respondents interviewed in Onwe belonged to a religious group. Comparatively, belonging to more groups and associations is in line with the ideas of Putnam et al. (1993) and Putnam (1995). It can be said that social bonds and interactions are stronger in Onwe than in Kwaso as citizens' participation in groups and associations in Onwe is better than that of Kwaso.

\section{Trust among the people}

Although cooperation between community members and local authorities is important for the benefits of community development, as noted by many of the respondents, such partnership was found to be low in Kwaso. Over 90 percent of 
the respondents revealed that there was low level of trust between neighbours and between community members and the traditional authority, which is supposed to play a leading role in community development in Kwaso. Comparatively, such partnership was rather strong in Onwe because of a higher level of trust among the neighbours and between community members and their leaders (see Table 2).

Table 2: Trust in neighbours and traditional authority

\begin{tabular}{|c|c|c|c|c|}
\hline \multicolumn{5}{|c|}{ Trust in Neighbours } \\
\hline \multirow[t]{2}{*}{ Community } & \multicolumn{2}{|l|}{ Onwe } & \multicolumn{2}{|l|}{ Kwaso } \\
\hline & Frequency & Percentage & Frequency & Percentage \\
\hline Always & - & - & - & - \\
\hline Mostly & 15 & $37 \cdot 5$ & - & - \\
\hline Sometimes & 20 & 50 & 28 & 70 \\
\hline Rarely & 5 & 12.5 & 12 & 30 \\
\hline Never & - & & - & - \\
\hline Total & 40 & 100 & 40 & 100 \\
\hline \multicolumn{5}{|c|}{ Trust in traditional authority } \\
\hline \multirow[t]{2}{*}{ Community } & \multicolumn{2}{|l|}{ Onwe } & \multicolumn{2}{|l|}{ Kwaso } \\
\hline & Frequency & Percentage & Frequency & Percentage \\
\hline Always & 4 & 10 & - & - \\
\hline Mostly & 16 & 40 & 4 & 10 \\
\hline Sometimes & 8 & 20 & 6 & 15 \\
\hline Rarely & 7 & 17.5 & 8 & 20 \\
\hline Never & 5 & 12.5 & 22 & 55 \\
\hline Total & 40 & 100 & 40 & 100 \\
\hline
\end{tabular}

Source: Field survey, January, 2017

Table 2 shows that about 38 percent of the respondents in Onwe would 'mostly' trust their neighbours and 50 percent would 'sometimes' do so. In the case of Kwaso, none of them indicated that they would 'mostly' trust their neigbhours. However, 70 percent of them would 'sometimes' do so. This suggests that Onwe community has a higher level of social capital in the form of trust among neighbours as compared to Kwaso. This is further supported by the finding that majority of respondents in Onwe trust the traditional authority. A total of 70 percent of respondents answered that they trusted the traditional authority. Table 2 also reveals that in Kwaso it was only 25 percent of respondents who indicated 
that they trusted the traditional authority. Some of the reasons explaining why this was the case in Kwaso as given by some of the community members were that:

The traditional authority is not interested in the welfare of community members. The chief is ripping some community members off their livelihoods by selling their farmlands without their consent. The traditional authority is only looking out for its own benefit and not the generality of the people. The chief does not use some of the proceeds from the sale of lands for community development. He does not reside in the community so I do not think he can be trusted to appreciate the needs and concerns of community members (Community member, Kwaso, November 2016).

The chief has not been able to successfully accomplish anything in the community for it to serve as a basis to trust him with the development of the community. Even the palace he says he is building has taken more than four years and is still not complete (Community member, Kwaso, November 2016).

These statements suggest that community members in Kwaso cannot point to successes of community leaders, neither could they tell of the leaders meeting their expectations. This discourage members from building trusting relations with the traditional authority and also committing to development efforts. This finding supports Putnam et al.'s (1993) assertion that to help bring a community to an action for community development, community members must trust the leaders which can create cooperation in ensuring that common goals within the community are accomplished much more smoothly.

\section{Civic Engagement}

The interest of community members in public agenda and their willingness to take responsibility for their community is an important element of social capital that was considered in this study. In terms of citizen's involvement in action to help address their own problems, the study found that civic engagement among community members was higher in Onwe than in Kwaso. The data in Table 3 show that members of the Onwe community have engaged more with the relevant institutions and individuals to address their problems. These include contacts with radio and television stations and traditional authority. Community members make such contacts so that they can voice out their concerns about issues regarding the community's development. Using contacts with local radio stations, a number of 
social networks in the form of PD groups (fun clubs) had been established in the community. Apart from the help that these PD groups offer members in achieving their potentials, some also offer financial and emotional support which contributes to improving the well-being of their members. The attendance of community or neighbourhood fora to discuss local issues helped them to identify and agree on community needs. As discussed later in the paper, out of such meetings, plans were made that led to the construction of a market, a chief's palace and the construction of a school block for Onweman Senior High School in Onwe.

Table 3: Attempts towards addressing community problems

\begin{tabular}{|c|c|c|c|c|}
\hline \multirow{3}{*}{$\begin{array}{l}\text { Various Actions to } \\
\text { Address Community } \\
\text { Problems }\end{array}$} & \multicolumn{4}{|l|}{ Community } \\
\hline & \multicolumn{2}{|l|}{ Onwe } & \multicolumn{2}{|l|}{ Kwaso } \\
\hline & Frequency & Percentage & Frequency & Percentage \\
\hline None & 5 & 12.5 & 20 & 50 \\
\hline $\begin{array}{l}\text { Contacted a local radio } \\
\text { station or television } \\
\text { station }\end{array}$ & 3 & 7.5 & 2 & 5 \\
\hline $\begin{array}{l}\text { Contacted Traditional } \\
\text { authority }\end{array}$ & - & & - & \\
\hline $\begin{array}{l}\text { Contacted the } \\
\text { Assemblyman/Unit } \\
\text { Committee }\end{array}$ & 8 & 20 & 6 & 15 \\
\hline $\begin{array}{l}\text { Attended a community } \\
\text { meeting or neighbourhood } \\
\text { forum to discuss local } \\
\text { issues }\end{array}$ & 20 & 50 & 10 & 25 \\
\hline $\begin{array}{l}\text { Have taken three actions } \\
\text { (except contact with radio } \\
\text { station) }\end{array}$ & 1 & 2.5 & - & - \\
\hline Have taken all four actions & 1 & 2.5 & - & - \\
\hline $\begin{array}{l}\text { Contacted a local radio } \\
\text { station and attended } \\
\text { community meeting or } \\
\text { neighbourhood forum to } \\
\text { discuss local issues }\end{array}$ & 2 & 5 & - & - \\
\hline $\begin{array}{l}\text { Contacted the } \\
\text { Assemblyman/Unit } \\
\text { Committee and attended } \\
\text { community meeting or } \\
\text { neighbourhood forum to } \\
\text { discuss local issues }\end{array}$ & - & - & 2 & 5 \\
\hline Total & 40 & 100 & 40 & 100 \\
\hline
\end{tabular}

Source: Field survey, January, 2017 
On the other hand, civic engagement in Kwaso was found to be low. This suggests that community members did not have a positive attitude towards community development and were not motivated to take actions that are beneficial for the community at large (refer to Table 3). The situation in Kwaso community together with other factors appear to have affected participation in community activities that in turn negatively affect community development.

\section{Social Norms of Fairness and Honesty}

Sensitivity to social norms is important in community development. This is because it instills in community members a sense of obligation towards others in the community and encourages cooperation among community members (Shoemaker, 2015).

As noted by Hardin (2004), cooperative behaviour is substantially regulated by communal norms. Many participants of the study appreciated the importance of fairness as a social norm for community development. Perceived fairness in each of the communities was assessed by asking the question 'Do you think most people in this community would try to be fair by being honest with you in their dealings?' The results show that fairness was more prominent in Onwe because majority of respondents would try to be fair and honest in their dealings with each other. In the case of Kwaso, the figures indicate that a greater percentage of respondents (65\%) would not be honest with their neighbours (see Table 4). It also appeared that the Onwe community was more willing to punish unfairness by mostly appealing to the traditional authority compared to that of Kwaso.

Table 4: Perceived fairness in communities

\begin{tabular}{|l|l|l|l|l|}
\hline \multicolumn{2}{|l|}{ Onwe } & \multicolumn{2}{l|}{ Kwaso } \\
\hline & Frequency & Percentage & Frequency & Percentage \\
\hline Would be fair/honest & 28 & 70 & 14 & 35 \\
\hline Would not be fair/honest & 12 & 30 & 26 & 65 \\
\hline Total & $\mathbf{4 0}$ & $\mathbf{1 0 0}$ & $\mathbf{4 0}$ & $\mathbf{1 0 0}$ \\
\hline
\end{tabular}

Source: Field survey, January, 2017

Generally, the findings show that social capital has contributed in producing positive influence on the success of community development initiatives in Onwe than Kwaso. These positive effects were noted around the participation of residents in community development activities, the ability of community members to work together, high awareness of community issues and the implementation of projects. 


\section{Participation in Community Activities}

Participants of the household interviews were asked to mention development projects that had been undertaken in their respective communities over the past five years. Based on this information, the study explored whether they had participated in these projects by way of contributing resources. According to the results in Table 5, participation in development activities was high in Onwe while that of Kwaso was low, about 88 percent of respondents in Onwe participated in development projects. Comparatively only 30 percent of respondents in Kwaso participated in development projects.

Table 5: Participation in development projects

\begin{tabular}{|l|l|l|l|l|}
\hline \multirow{2}{*}{ Response } & \multicolumn{2}{|l|}{ Onwe } & \multicolumn{2}{l|}{ Kwaso } \\
\cline { 2 - 5 } & Frequency & Percentage & Frequency & Percentage \\
\hline Did participate & 35 & 87.5 & 12 & 30 \\
\hline Did not participate & 5 & 12.5 & 28 & 70 \\
\hline Total & 40 & 100 & 40 & $\mathbf{1 0 0}$ \\
\hline
\end{tabular}

Source: Field survey, January, 2017

Resources that members contributed to support development projects include labour, money and time. Members of the Unit Committee from Onwe explained how community members contributed to development activities:

The community engages in communal labour which is organised by communityleaders on Fridays around development projects so that our people can contribute their quota as citizens of the community (Unit Committee member, Onwe, November 2016).

We make monetary contributions towards development projects in the form of community levy. The community levy is paid by adults who are working and ranges from GHc 5 to Ghc 20. The monies are used to support community-led development initiatives (Unit Committee member, Onwe, November 2016).

These statements reveal how community members supported development projects as explained by community leaders. These claims were corroborated by community members themselves as some of them noted they carried blocks, concrete and mortar to build the market and chief's palace. One of the respondents noted: I helped in weeding around the site for the school, market and chief palace. I also carried blocks and sand. I paid the community levy which was used in the construction of the market (Community member, Onwe, November 2016). 
Unlike Onwe, majority of community members in Kwaso did not support development projects (see Table 5). When asked about the reason for the low participation, a high profile member of the Unit Committee indicated that:

For the past eight years, the entire community has not been organised in communal activities. This is because community members have had some issues with the leadership (traditional authority and Unit Committee) regarding the use of community levy and community governance. In the past, community members paid community levy which was collected by the Unit Committee. This money was supposed to be used for development projects and the Unit Committee was to give a yearly account of what the community levy was used for. The Unit Committees failed to give proper account which affected the payment of the community levy and the commitment of community members towards communal activities (Unit Committee member, Onwe, November 2016).

These claims point to the fact that attitudes of community leadership can shape peoples commitment to community development. Leaders that are seen as being more accountable, transparent and committed to the good cause of the community can engender trust among local people and result in the people giving their best in terms of funds, time and unpaid labour towards community development.

\section{Working Together}

Another finding was that Onwe had a sense of unity that facilitated the ability of community members to work together and engage in communal activities. The major reason that explains this was the issue of governance. The community leadership operated a transparent governance where community members could approach leaders with their concerns. There were avenues provided for members to voice out their concerns as explained by one of the community members:

Each year, the leadership of the community meets with us two weeks before the Easter festival to give account of what they used the community levy for. Again, the leaders hold a community durbar during the Easter period where the community discusses the way forward in terms of community development (Community member, Onwe, November 2016).

It was also found that apart from these meetings, community members got the opportunity to meet the leaders every month. A high profile member of the Traditional Council noted: 
This is the time when drinks brought to the traditional authority by families of deceased people who would be organising funerals in the month are distributed to community members present. This meeting is held at the community centre, and by this encounter, community members are able to voice out their concerns (Traditional council member, Onwe, November 2016).

These responses suggest that community leaders have been able to establish networks with community members through community-wide interactions. Community durbars and other meetings seemed satisfying to community members and served as a motivation for members to become more involved in reaching shared objectives. Community participation in Onwe has therefore been greatly influenced by opportunities offered by community leaders to share ideas with community members.

Meanwhile in Kwaso, the community appeared divided and so community members could not be organised to pursue communal activities. For example, when asked about the community's ability to work together, one community leader explained that:

The entire community is against the traditional authority and because of that they do not want to support community activities. For this reason, no matter the merit of an initiative taken by the traditional authority, community members refuse to participate (Community member, Onwe, November 2016).

This claim was validated by the focus group discussion. During the focus group discussions, the views of a member as supported by all the others present were that:

Community activities do not get the support of community members. It has been a challenge for us as a new administration to engage community members in any communal work. The community is divided into two factions, the traditional authority on one side and community members on the other. The cause of this problem is the way the traditional authority is governing the community. Community members have complained about the fact that the traditional authority has not been accountable enough to them and fails to let them in on new developments in the community. For instance, last year community members demonstrated against the traditional authority for not informing them beforehand about the activities of a quarry company in the community (Member of Focus Group, Onwe, November 2016). 
It can be inferred from these statements that the traditional authority in Kwaso does things contrary to what the community members expect. For this reason, they are not attracted to lend their support to communal activities. The behaviour of the community leadership therefore serves as a disincentive.

\section{Knowledge of Community Issues}

A well-informed citizenry is necessary to engender community participation, and for the overall development of local communities. Although development depends on the people's ability to produce, access and use pertinent information (Harande, 2009), the study found that in Kwaso, community members were less-informed while community members in Onwe were more informed about community issues (see Table 6).

Table 6: Level of knowledge of community issues

\begin{tabular}{|l|l|l|l|l|}
\hline Community & \multicolumn{2}{l}{ Onwe } & \multicolumn{2}{l|}{ Kwaso } \\
\hline & Frequency & Percentage & Frequency & Percentage \\
\hline Well-informed & 30 & 75 & 18 & 45 \\
\hline Somewhat-informed & 8 & 20 & 14 & 35 \\
\hline Not well informed & 2 & 5 & 8 & 20 \\
\hline Total & $\mathbf{4 0}$ & $\mathbf{1 0 0}$ & $\mathbf{4 0}$ & $\mathbf{1 0 0}$ \\
\hline
\end{tabular}

Source: Field survey, January, 2017

Participants in the focus group discussion made similar statements about how poorly informed citizens of Kwaso were. According to one of them:

In year 2014, the youth of the community demonstrated against the traditional authority because of lack of information about the operations of a quarry company. Community members woke up one day and saw trucks of gravels leaving the community. A followup to this new development showed that the traditional authority had given permit to the company to mine stones for construction. The youth got infuriated because they were not aware of this new development and so demonstrated against the traditional authority (Community member, Kwaso, November 2016).

Since whether or not citizens are informed about plans and goals of community leaders and public issues affect their participation, it can be concluded that the high participation of community members in Onwe is partly because they are well informed about issues affecting their community. Community members in 
Kwaso were less informed about community issues mainly because no avenues were created for interactions with community leaders. Community members again did not have the opportunity to make their concerns known and hold leaders to account for their stewardship.

\section{Initiation of Community Projects}

The Onwe community in partnership with the Electricity Company of Ghana got the community connected to the national grid. At the initial stage, community members themselves mobilized to acquire the teak trees needed and erected the poles along the main road from Ejisu to Onwe. This act then induced cooperation from the Electricity Company of Ghana to connect them to the grid. According to a key informant; "The ECG was quick to come in because we had mobilized and erected the poles. We were successful because of the high communal spirit" (Key informant, Onwe, November 2016). A member of the Unit Committee also confirmed the effects of high communal spirit in Onwe. He explained:

Recently, community members realising that the market in the community was small in size and unsafe because it was located close to the main road decided to construct a new market. This project was initiated and completed solely by community members and leaders. This was made possible through the assembly members working together with the traditional authority (Unit Committee member, Onwe, November 2016).

It can be concluded from these statements that the establishment of these projects was made possible because of strong social networks, trust, civic engagements and social norms. It must be noted that the community's ability to use their vertical networks to reach out to individuals inside and outside the community is an important element in the community development process. The trust and norms also enhanced cooperation among community members and leaders towards community development resulting in the construction of a community market (Figure 2), and chief's palace (Figure 3 ). 


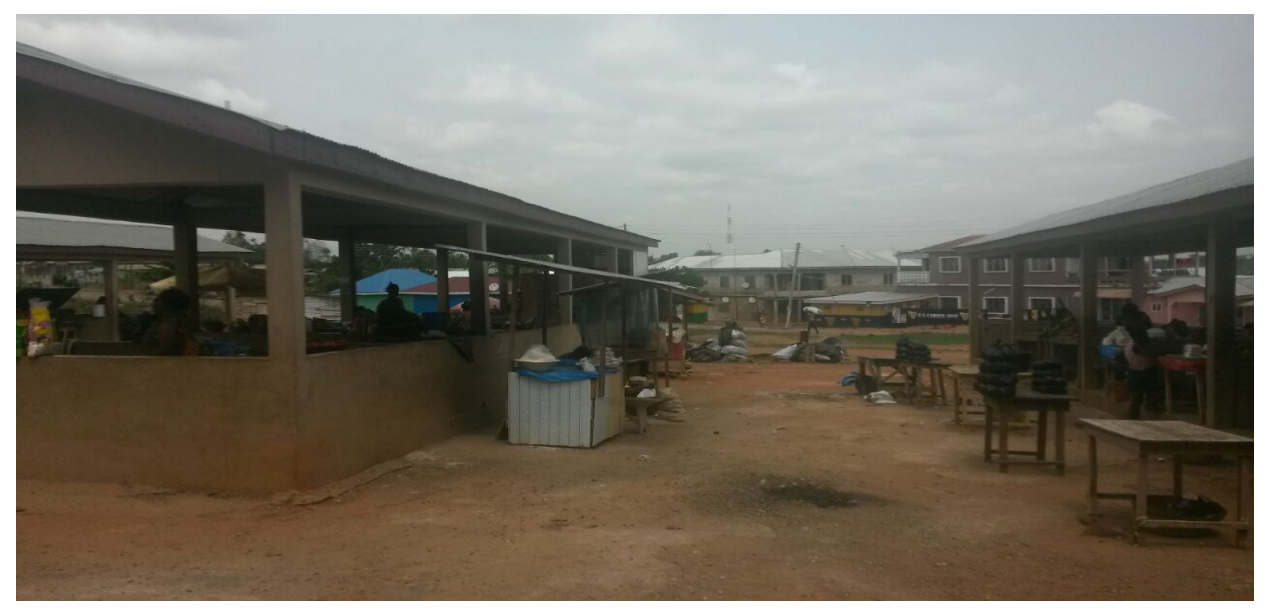

Figure 2: Community market at Onwe

Source: Fieldwork, November 2016

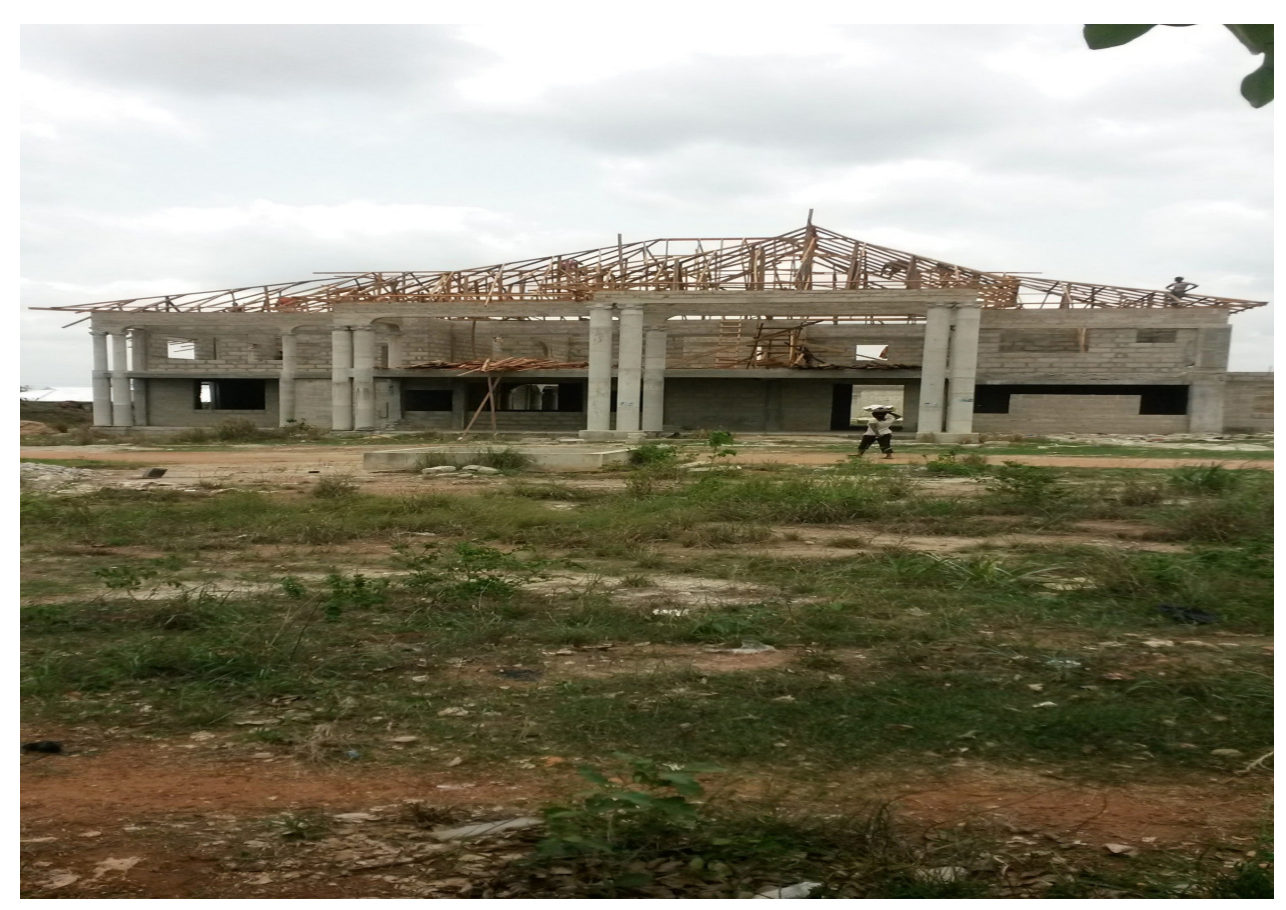

Figure 3: Chief's palace at Onwe under construction

Source: Fieldwork, November 2016 


\section{Conclusions and Recommendations}

The findings of this study support the claims that there is a correlation between community development and the level of social capital. Development projects flourished in Onwe where there was a higher level of social capital. For Kwaso community, the low level of social capital contributed to the absence of support for community-based initiatives.

This paper argued that social capital is a major determinant of community development and must be considered by all institutions involved as a key ingredient in the activity of planning community development.

As part of the community development planning process, community residents can be empowered to help address their own needs. The Municipal Assembly and the Development Planning Unit of sub-national governments need to organise community meetings where values such as self-help and volunteerism can be promoted.

Planning activities typically require the inclusion of community views through community participation. Officials involved in community development can engage and interact with community members in groups and associations. This will help build relationships of trust within which the opinions and needs of community members can be explored and effectively addressed.

There is the need for restructuring models used in the training of sub-national public officers to incorporate ideas of social capital. The benefits of social capital, its potential to facilitate community action; and the ways in which the concept of social capital can enhance planning efforts need to be highlighted.

\section{References}

Adjargo, G. (2012). Social capital: an indispensable resource in Ghana. Journal of Sustainable Development in Africa, 14 (3), pp. 219-227.

Billett, P. (2012). Indicators of Youth Social Capital: The Case for not Using Adult Indicators in The Measurement of Youth Social Capital. Youth Studies Australia, 31(2), pp. 9-16.

Bullen, P. (2007). Community development models and language. Available at: http:// www.mapl.com.au/ideas/. Accessed: $18^{\text {th }}$ May 2015.

Butler, B. Pick, D. and Dayaram, K. (2009). Social capital as the missing link in the growth process: implications for strategic orientation of businesses 
and sustainable regional development in a remote location. Problems and Perspectives in Management, 7 (1), pp.40-48.

Cavaye, J. (2001). Rural community development: new challenges and enduring dilemmas. Journal of Regional Analysis and Policy, 31 (2), pp. 109-124.

Cavaye, J. (2004). Social capital: a commentary on issues, understanding and measurement. Available at: http://pascalobservatory.org/content/socialcapital. Accessed: 6th April, 2015.

Coleman, J. S. (1988). Social capital in the creation of human capital. American Journal of Sociology, 94, pp. S95-S120.

Conyers, D. and Hills, P. (1984). An introduction to planning in the third world. Chichester: John Wiley \& Sons Ltd, pp. 6o-65.

Debertin, D. L. and Goetz, J. S. (2013). Social capital formation in rural, urban and suburban communities. Available at: www.uky.edu/ deberti/socsaea. Accessed: 4th May, 2016.

Dhesi, A. S. (2000). Social Capital and Community Development. Community Development Journal, 35(3), pp. 199-214.

Ejisu-Juaben Municipal Assembly (2010). District Medium-Term Development Plan (2010-2013). Accra, Ghana: Ministry of Local Government and Rural Development.

Eriksson, M. (2010). Social Capital, Health and Community Action - Implications for Health Promotion. Available: Umeå University Medical Dissertation. Available at: www.diva-portal.org/smash/record. Accessed: 5th April 2015

Friedman, M. A. and Fraser, A. V. (2015). Social capital and community planning, in J. M. Halstea and S. C. Deller (Eds.) Social Capital at the Community Level: An Applied Interdisciplinary Perspective, pp. 114-133. New York: Routledge.

Ghana Statistical Service (2014). 2010 Population and housing census district analytical report: Ejisu-Juaben Municipal. Accra: Government of Ghana.

Grootaert, C. (1998). Social capital: the missing link? Social Capital Initiative working paper series; no.3. Washington, D.C.: The World Bank.

Harande, Y. I. (2009). Information services for rural community development in Nigeria. Library Philosophy and Practice (e-journal), Paper 271.

Hardin, R. (2004). From communal norms to networks. Paper delivered to the Conference, "Trust and Asia," of the Harvard Project for Asian and International Relations. Shanghai: 1 May. 
Hawe, P., and Shiell, A. (2000). Social capital and health promotion: a review. Social Science \& Medicine, 51(6), pp. 871-885.

Holman, N. and Rydin, Y. (2012). What can social capital tell us about planning under localism? Local Government Studies, 39 (1), pp. 71-88.

Hua, C. W. and Wan, K.E. (2011). Civic mindedness: components, correlates and implications for the public service. Available at: http://www.cscollege.gov.sg. Accessed: 15th February 2016.

Innes, J. E. and Booher, D. E. (2010). Planning with complexity: An introduction to collaborative rationality for public policy. New York: Routledge, pp. 165- 170.

Kennedy, M. (1996). Transformative community planning: empowerment through community development. Paper delivered to the 1996 Planners Network Conference on Renewing Hope, Restoring Vision: Progressive Planning in Our Communities, Brooklyn, 14-16 June.

Kent, G. (1981). Community-based development planning. Third World Planning Review, 3 (3), pp.313-326.

Litman, A. T. (2013). Planning principles and practices. Available at: www.vtpi.org/ planning.pdf. Accessed: $27^{\text {th }}$ November 2015.

Maclaran, A., Clayton, V. and Brudell, P. (2007). Empowering communities in disadvantaged urban areas: Towards greater community participation in Irish urban planning?' (Working Paper Series 07/04), Dublin, Combat Poverty Agency.

Mendes, P. P. (2009). Teaching community development to social work students: A critical reflection. Community Development Journal, 44 (2), pp. 248-262.

Miruka, C. O. and Omenya, A. O. (2009). Social capital, public provisioning ademocratic governance. Available at: http://hdl.handle.net/2027/spo.4761563.0006.101. Accessed: $5^{\text {th }}$ December, 2016.

Myjoyonline (2015). Ejisu-Juaben Municipal Assembly Adjudged the best in 2014 . Available at: http://myjoyonline.com/news/2015/January $23 \mathrm{rd} /$. Accessed: $1^{\text {st }}$ February 2016.

Phillips, R. and Pittman, R. (Eds.) (2008). An Introduction to Community Development. London, Routledge, pp. 58-60.

Portes, A. (1998). Social Capital: Its origins and applications in modern sociology. Annual Review of Sociology, 24(1), pp.1-24. 
Putnam, R. and Goss, K. A. In Putnam R. (Eds.) (2002). Democracies in Flux: The Evolution of Social Capital in Contemporary Society. Oxford University Press, Inc., New York.

Putnam, R. (1993). The Prosperous Community: Social Capital and Public Life. The American Prospect, Volume 4, Issue 13. pp. 35-42

Putnam, R. D. (1995). Bowling alone: America's declining social capital. Journal of Democracy, 6 (1), pp. 65-78.

Putnam, R. D., Leonardi, R. and Nanetti, R. Y. (1993). Making Democracy Work: Civic Traditions in Modern Italy. Princeton, N.J., Princeton University Press.

Rydin, Y. and Pennington, M. (2000). Public participation and local environmental planning: the collective action problem and the potential of social capital. Local Environment, 5 (2), pp. 153-169.

Shoemaker, D. (Ed.) (2015). Oxford Studies in Agency and Responsibility (Volume 1), New York: Oxford University Press, UK.

Thomas, G. (2014). How to do your case study: A guide to students and researchers. London: SAGE Publications.

Tirmizi, S. N. A. (2005). The contribution of levels of social capital to community development. Retrospective Theses and Dissertations Paper 1599, Iowa: Iowa State University.

Todaro, M. P. and Smith, S. C. (2011). Economic Development (11th Ed.), Boston: Addison Wesley Longman.

Tzanakis, M. (2013). Social Capital in Bourdieu's, Coleman's and Putnam's Theory: Empirical Evidence and Emergent Measurement Issues. Educate, 13(2), pp. 2-23.

Van Dusseldorp, D. B. W. M. (1991). Scientific sociological knowledge and its usefulness for the planned development process: its potentials and limitations In S. B. Dahiya (Ed.) Theoretical Foundations of Development Planning, pp. 365-400. New Delhi: Concept Publishing Company.

Van Kinderen, I. E. (2006). Social Capital in Rural Dry Season Farming Communities and its Effect on the Use and Implementation of Small Water Reservoirs. (unpublished Masters' Thesis), Delft: Delft University of Technology.

Wiesinger, G. (2007). The Importance of Social Capital in Rural Development, Networking and Decision-Making in Rural Areas. Journal of Alpine Research 95(4), pp. 43-56. 
Woolcock, M. and Narayan, D. (2000). Social Capital: Implications for Development Theory, Research, and Policy. The World Bank Research Observer, 15, pp. 225-249.

World Bank Group (2014). Community-driven development (online). Available at: http://www.worldbank.org/en/topic/communitydrivendevelopment/ Accessed $2^{\text {nd }}$ October 2014. 